\title{
Cell Formation Based on New Similarity Coefficient with Operation Sequence and Alternative Routing
}

\author{
S. Raja, K. Muralidharan, S. Karthik, K. Rajasuthan
}

\begin{abstract}
Cell formation is to construct machine cells and part families and then dispatch the part families to machine cells. Various cell formation approaches and algorithms have been developed over the years considering various production factors, scenarios and objectives. The results of these different approaches are evaluated based on the several parameters. Most of the studies have considered only either the operation sequence or the alternative routing. Very few of the approaches have proposed for considering both the operation sequence and the alternative routing. Here, a new method for the formation of cell and intracellular machine arrangement which is formulated by considering both the operation sequence and alternative process routings is proposed. The arrangement of machines and parts within the cell follows a specific sequence which is formed with the help of coefficient of similarity. Various parameters such as forward flow, backflow and voids in the cell formation scenarios are considered to evaluate the approach. With the help of these parameters problems from other literatures, which were solved by other methods are evaluated. So as to validate the effectiveness of our proposed approach, five eminent test problems from the previous literature are engaged and the results are compared with the existing method the results clearly display that the proposed approach which that provides superior or equal solution than the existing method.
\end{abstract}

Keywords: Alternative routing, Cellular manufacturing System, Operation sequence, Part family, Similarity coefficient,

\section{INTRODUCTION}

Cellular Manufacturing is one of the primary applications of group technology principles in manufacturing. It can be defined as a technique which enforces a flexible manufacturing system and ensures higher production rate. The main goal of cellular manufacturing is to reduce flow time.

Revised Manuscript Received on November 30, 2019.

* Correspondence Author

Dr.S.Raja* Professor, Department of Mechanical Engineering, PSNA College of Engineering and Technology, Dindigul-624622. Email: maduraisraja@gmail.com

Dr.K.Muralidharan Professor, Department of Mechanical Engineering, PSNA College of Engineering and Technology, Dindigul-624622. Email: muralidha@gmail.com

S..Karthik, Assistant Professor, Department of Mechanical Engineering, PSNA College of Engineering and Technology, Dindigul-624622. Email: karthiksmp@gmail.com

K.Rajasuthan, Assistant Professor, Department of Mechanical Engineering, PSNA College of Engineering and Technology, Dindigul-624622. Email: rajasuthan82@gmail.com

(C) The Authors. Published by Blue Eyes Intelligence Engineering and Sciences Publication (BEIESP). This is an open access article under the CC-BY-NC-ND license http://creativecommons.org/licenses/by-nc-nd/4.0/
This can be achieved by increasing the forward flow as maximum as possible and also at the same time reducing the backflows and voids in the system. First, the similarity coefficient between all the machines with every other machine is calculated based on the new proposed similarity coefficient. The new similarity coefficient includes the number of common parts processed between the corresponding two machines. The cells are formed based on the similarity coefficient values. Then, the intracellular machine arrangement is carried out by forming the index matrix and selecting the best sequence of machines in order to achieve the maximum possible forward flows. The final result is compared with the results of other approaches and inference has been made. The basics of cellular manufacturing systems are to find the part families and machine cells so that the intercellular movements can be reduced which in turn will reduce the overall production time. Various approaches have been proposed for cell formation among which similarity coefficient method is an effective one. The results of the similarity coefficient method depend only on the similarity coefficient formula. The ability of the formula to determine the relationship between two machines will influence the cell formation. In our algorithm, we have proposed a new similarity coefficient formula for cell formation and an index matrix for intracellular machine arrangement.

\section{LITERATURE REVIEW}

Chin-chi et al (2013) proposed an efficient approach to determine cell formation, cell layout and intracellular machine sequence in cellular manufacturing system. It comprises of two stages. The first stage involves the use of HTSCF (Hybrid Tabu Search for Cell Formation) algorithm for cell formation and cell layout. The second stage involves the use of same algorithm for intracellular machine layout (ie., the arrangement or sequence of machines in each cell). The results concluded that by the end of first stage of the algorithm, the intercellular movements are reduced, and by the end of the second stage, the forward flows have been increased. Murugan and Selladurai (2011) put forth an ART modified single linkage clustering approach for the formation of cells and part families in cellular manufacturing. In this approach, ART1 network is integrated with Modified Single Linage Clustering. In this methodology, the cell formation is first constructed using the ART1 and then the solution is refined using the Modified Single Linkage Clustering.

\section{IJITTEE}

Published By: 
The results are compared with popular existing algorithms and concluded that the proposed methodology produced effective results and the computation effort was also low when compared with other methodologies. Chalapathi (2012) proposed a complete design of cellular manufacturing system. This methodology works in four phases. In the first phase, the method finds natural seeds in which the approach chooses the seed points from the data set itself, so that each point represent and enter first into each cluster. In the second phase an approach is made to reduce the number of machines in cells. In the third phase, the cells and their families are refined after allowing inter cell operations. The final phase of methodology is concerned with designing the arrangement (best sequence) of machines in each cell and also the cells themselves. Amit and Mishra (2007) proposed a heuristic based approach of cell formation considering the operation sequence. It is a two stage heuristic based procedure for generating part family and machine cell formation in cellular manufacturing system. During the first phase a bottom up procedure is followed for machine grouping. Upper bound on the cell formation which was imposed during the first phase will be relaxed by the second phase (ie., refining of the solution happens in the second phase in this approach). The was found to produce quality solutions. Teymourian et al (2011) put forth a new cell formation model using sequence data and handling cost factors. They also included additional cost of utilizing a machine in an outsider part cell as well as handling cost components. In this study four cost components, movement cost for a part for processing two successive operations - in the same cell , within an external cell, through two different cells and an additional variable cost for the machine supposed to process operation of a given part, in such a way that regarded machine is not within the cell of the part. Farouq(2013) gave a clustering algorithm for solving group technology problems with multiple process routings. He formed a new comprehensive similarity coefficient that incorporated multiple process routings in addition to the operation sequence, production volumes, duplicate machines and machine capacity. This algorithm comprises two stages. The first stage produces an initial solution for machine cells and part families. During the second stage, the required capacity of each machine is checked and duplicate machines are assigned to the required cells in order to reduce the inter cellular movements. The proposed procedure produced the better solutions with minimum possible intercellular moves.

Raja and Anbumalar (2016a) developed a new heuristic approach CLASSPAVI for cell formation problem and intra cell layout. .Mohammad \& jamal (2008) focused on the configuration of machine cells considering production volumes and process sequences of parts. Also they used Alternative Process Routings (APR) for part types by considering the reliability of the machines. Their main objective is to minimise total cost of intercellular movements. They developed a binary integer programming model to deal with this situation. By considering the reliability of the machines that makes undesirable changes in the block diagonal machine-part matrix thus the overall cost of the cellular system reduced considerably. proposed algorithm was also tested with large problems and it

Raja and Anbumalar (2016b) introduced a new method for integrating feasibility assessment and cell formation problem considering operation sequence. Hamed et al (2013) proposed a cell formation in dynamic condition with multiple alternative process plans and a set of set of alternative routes for each of process plans. Also addressed the defect rate. They developed a hybrid meta-heuristic approach to cope up with the CF problem. They gave the cell formation problem in which each part has different alternative process plans and for each process plan there is set of machines or different alternative routes. Their objective is to minimize the cell formation costs as well as the costs associated with the production. They used GAMS software package for solving the mathematical model with hybrid algorithm for small and medium size problems. Manash and Dipak (2016) proposed a heuristic approach based on Euclidean Distance matrix for CF in multiple routes, process sequential and part volume problems. Their proposed approach is competitive or better than the previous proposed algorithms in terms of intercellular movements of parts. They used Single Linkage Clustering (SLC) for grouping process. This clustering algorithms covert the machine-part incidence matrix into some diagonally arranged blocks where each block represents a combination of one machine cell and a part family. Then they used Euclidean Distance Matrix (EDM) in which Euclidean distances of machine for processing parts considering part volume, batch size, and number of batches are calculated and clustering is done by SLINK for minimum Euclidean distance. Their main motive is to generate optimum machine cells having minimum intercellular movement of parts. Sani et al (2009) proposed a new cell formation algorithm, considering the factors sequence of operation, alternative routing and part-volume to cope up with the designing of a cellular manufacturing system. They introduced a optimised cell formation algorithm consisted of five major steps. They formulated this algorithm to minimise the total number of inter-cell travel. This numerical proposed problem indicates the efficiency of the cell formation algorithm that integrates the three manufacturing criteria i.e., sequence of operations, alternative routing, and part-volume. Chin-Chih et al proposed a two-stage approach to integrate cell formation, cell layout, and intracellular machine layout simultaneously with the considerations of operation sequences, alternative process routings, and production volume. They used NP-hard and Tabu Search (TS) for both stages. This proposed approach is very effective, efficient, and practical. The first stage comprises of the cell formation and the cell layout are jointly determined based on the minimization of total ICMD. In second stage, they proposed the HTSCF for the intracellular machine layout. They also compared their solutions with the previous proposed model to indicated their proposed algorithm for the cell formation is more efficient. Chin-Chih and Tai-His (2011) adopted the Water Flow-like Algorithm (WFA) logic and designs a heuristic algorithm for solving the cell formation and cell layout problems simultaneously. 
Their way of mathematical programming approach would take only one hour to solve it when compared to other approaches. They also showed that their proposed approach is extremely effective and efficient. The design of the WFA was inspired by the natural behaviour of water flowing from higher to lower levels. This WFA algorithm consists of four primary operations: (1) flow splitting and moving, (2) flow merging, (3) water evaporation, and (4) precipitation. The results of the proposed method were compared with the optimal solutions obtained by the LINGO 8.0 software. This comparison showed that the proposed method offers good solutions for the CFP considering production volume, production sequence, alternative process routings and cell layout. Nittaya and Busaba (2011) proposed a cellular layout manufacturing design based on the systematic layout planning and selection of facilities layout design by analytic hierarchy process.

This methodology consists of six main procedures as follows: i) Making relationship chart and from-to chart ii) Relationship diagram iii) Space requirements iv) Space Relationship Diagram v) Alternative layouts evaluation vi) Layout Selection and Installation. The result of the evaluation of this case study showed that the proposed layout was best based on the evaluated weight of criteria - material handling, layout characteristics, cost and flexibility.

\section{PROBLEM DEFINITION}

Various approaches have been introduced so far for efficient cell formation. Very few of them involved alternative routing concepts and machine sequencing. A best approach should be in a way such that it can be applied to almost all cases to get a efficient result. Our approach is also based on increasing the efficiency of the result while considering alternative routings and intracellular machines sequencing.

\section{CELL FORMATION}

The first and most important thing in cellular manufacturing systems is the cell formation. Machines which are closely related to each other must be placed in the same cell. In other words, it can be said that the machines should be clustered in a way such that most of the parts will be processed within a single cell as far as possible. It will reduce the intercellular movement of the parts. We have proposed a new similarity coefficient formula which will result in an effective cell formation.

\section{INTRACELLULAR MACHINE SEQUENCE}

The next thing which is to be taken care of is intracellular machine sequence which is nothing but the arrangement of machines in each cell. This arrangement plays a vital role in determining the forward and backward flows in the cell. In our algorithm this intracellular machine sequence is made with the help of an index matrix. From the index matrix two parameters indicating the forward and backward flows are calculated and the best machine sequence is chosen based on the parameter values.

\section{METHODOLOGY}

\section{SIMILARITY COEFFICIENT}

We have proposed a new similarity coefficient for calculating the similarity between machines and parts which will lead to the formation of machine cells and part families. The similarity coefficient formula is given as

Similarity coefficient $=\frac{a+(a+d)^{2}}{\mathrm{a}+\mathrm{b}+\mathrm{c}+\mathrm{d}+(\mathrm{a}+\mathrm{d})^{2}}$

Where,

* 'a' represents the number of parts that utilise both the machines say ' $i$ ' and ' $j$ ' under consideration.

* 'b' represents the number of parts that utilise only machine 'i' but not machine ' $j$ '.

* 'c' represents the number of parts that utilise only machine 'j' but not machine ' $i$ '.

* 'd' represents the number of parts that utilise neither machine ' $i$ ' nor machine ' $j$ '.

We have proposed an algorithm for cell formation and intracellular machine sequencing by means of a new similarity coefficient and index matrix. The index matrix helps for intracellular machine arrangement. Our algorithm is clearly explained in steps in this section.

Step-1: First, the similarity coefficient is calculated for every machine with every each other machine so that the linkage between the most similar machines can be found. It ensures that the most similar machines are placed in the same cell.

Step-2: After the formation of similarity coefficient matrix, the maximum values from each row are taken and the corresponding machine linkages are noted down.

Step-3: Starting from the maximum linkage value, the machines are clustered to form cells. This process is continued until all the machines are brought into the cell.

Step-4: After that, the same similarity coefficient formula is used to calculate the similarity between the parts.

Step-5: Similar to the machine cell formation, the part families are formed.

Step-6: Then the machine cells are linked with the corresponding part families and the individual cell matrices are formed.

Step-7: The next step is to make an intracellular machine arrangement based on the sequence of operations. It is done by means of the index matrix.

Step-8: Starting from the foremost operation, the index of each operation is considered and the index matrix is formed.

Step-9: Two parameters are calculated from the index matrix which will indirectly indicate the forward flow and backward flow in the considered machine sequence. Then, the machine sequence is altered so that one of the parts flow through the cell in a sequential manner.

The effectiveness of the sequence is again calculated by means of the index matrix.

Step-10: This procedure is followed until all machine sequence combinations are evaluated.

Step-11: Finally, the best sequence of machines can be determined by means of the evaluations from the index matrix.

In case of systems with alternative routings the following steps must be followed prior to the common algorithm. First based on the similarity coefficient values, 
cell formation is made and the best route for each part is chosen based on the ICMD (Inter Cell Move Distance). After choosing the best route the common algorithm as mentioned above can be followed.

\section{ILLUSTRATIVE EXAMPLES}

This problem (Table 1 ) comprises of 10 machines and 10 parts. It is taken from the paper published by chin chih et al (2013).

Table 1: 10x10 Machine Part Matrix

\begin{tabular}{|c|c|c|c|c|c|c|c|c|c|c|c|}
\hline \multicolumn{2}{|c|}{ Machines } & \multirow[t]{2}{*}{1} & \multirow[t]{2}{*}{2} & \multirow[t]{2}{*}{3} & \multirow[t]{2}{*}{4} & \multirow[t]{2}{*}{5} & \multirow[t]{2}{*}{6} & \multirow[t]{2}{*}{7} & \multirow[t]{2}{*}{8} & \multirow[t]{2}{*}{9} & \multirow[t]{2}{*}{1} \\
\hline Parts & Routes & & & & & & & & & & \\
\hline \multirow[t]{3}{*}{1} & 1 & 1 & 2 & & 3 & & & & & & \\
\hline & 2 & & 2 & & 1 & & 3 & & & & \\
\hline & 3 & & & 1 & 2 & 3 & & & & & \\
\hline \multirow[t]{2}{*}{2} & 1 & & & & & 3 & & 2 & 1 & & \\
\hline & 2 & 1 & & & & 4 & & & & 3 & 2 \\
\hline \multirow[t]{3}{*}{3} & 1 & & 1 & & & & & 3 & 2 & & \\
\hline & 2 & 1 & & & & & & & 3 & & 2 \\
\hline & 3 & 1 & 2 & & & 3 & & & & & \\
\hline \multirow[t]{2}{*}{4} & 1 & & & 1 & & & & & 2 & 3 & \\
\hline & 2 & & & 1 & & & & 3 & 2 & & \\
\hline \multirow[t]{2}{*}{5} & 1 & 1 & & & & 3 & & & & & 2 \\
\hline & 2 & & 1 & & & 4 & & & & 3 & 2 \\
\hline \multirow[t]{3}{*}{6} & 1 & 1 & 2 & 3 & & & & & & & \\
\hline & 2 & & & 1 & & & & 3 & 2 & & \\
\hline & 3 & & & & & & 2 & & 3 & & 1 \\
\hline \multirow[t]{3}{*}{7} & 1 & & 1 & & 2 & & 3 & & & & \\
\hline & 2 & 1 & 2 & & 3 & & & & & & \\
\hline & 3 & & & & 1 & & & 3 & 2 & & \\
\hline \multirow[t]{2}{*}{8} & 1 & 1 & & & & 5 & & & 3 & 4 & 2 \\
\hline & 2 & 1 & & & & 3 & & & & 2 & \\
\hline \multirow[t]{2}{*}{9} & 1 & & & 1 & & 4 & & 3 & 2 & & \\
\hline & 2 & & & 1 & & & & & 2 & 3 & \\
\hline \multirow[t]{2}{*}{10} & 1 & 1 & & 2 & & & & 3 & & & \\
\hline & 2 & & & 1 & & & & 3 & 2 & & \\
\hline
\end{tabular}

Step1: Formation of Coefficient Matrix For Machines By means of the new coefficient formula, the coefficient matrix is formed for the machines and is shown in the Table 2 .

Step 2: Formation Of Machine Cells

By means of the matrix, the maximum coefficient values are taken from each row of the matrix and the corresponding links are shown below (Table 3).

From the above table, the machine cells are formed as:

$>$ Cell 1: machines 4, 6 \& 2

$>$ Cell 2: machines 7, 8 \& 3

Cell 3: machines 1,5,9 \& 10
Step 3: Selection Of Best Routing

ICMD is calculated for each route, and the route with the minimum ICMD is chosen as the best route. The ICMD values for various routes are chosen in Table 4.

Step 4: Formation Of Coefficient Matrix For Parts

In a similar way, the similarity coefficient matrixes for parts are also determined and shown in Table 5.

Table 2: Machine Coefficient Matrix

\begin{tabular}{|l|l|l|l|l|l|l|l|l|l|l|}
\hline $\mathbf{M}$ & $\mathbf{1}$ & $\mathbf{2}$ & $\mathbf{3}$ & $\mathbf{4}$ & $\mathbf{5}$ & $\mathbf{6}$ & $\mathbf{7}$ & $\mathbf{8}$ & $\mathbf{9}$ & $\mathbf{1 0}$ \\
$\mathbf{M}$ & & & & & & & & & \\
\hline $\mathbf{1}$ & - & 0.17 & 0.15 & 0.18 & 0.46 & 0.18 & 0.12 & 0.12 & 0.38 & 0.38 \\
\hline $\mathbf{2}$ & - & 0.15 & 0.38 & 0.15 & 0.38 & 0.25 & 0.25 & 0.18 & 0.18 \\
\hline $\mathbf{3}$ & & & - & 0.17 & 0.25 & 0.17 & 0.54 & 0.54 & 0.17 & 0.17 \\
\hline $\mathbf{4}$ & & & & - & 0.17 & 0.39 & 0.15 & 0.15 & 0.20 & 0.20 \\
\hline $\mathbf{5}$ & & & & & - & 0.17 & 0.23 & 0.23 & 0.38 & 0.38 \\
\hline $\mathbf{6}$ & & & & & & - & 0.15 & 0.15 & 0.20 & 0.20 \\
\hline $\mathbf{7}$ & & & & & & & - & 0.62 & 0.15 & 0.15 \\
\hline $\mathbf{8}$ & & & & & & & - & 0.15 & 0.15 \\
\hline $\mathbf{9}$ & & & & & & & & & - & 0.30 \\
\hline $\mathbf{1 0}$ & & & & & & & & & - \\
\hline
\end{tabular}

Step 5: Formation Of Part Families

The parts links are formed using coefficient matrix as shown below in the Table 6 .

Using table 6, the part families are formed as shown below

$>$ Part family 1: parts 1 \& 7

$>$ Part family 2: parts 4,10,6,9 \& 3

$>$ Part family 3: parts 2,8 \& 5

Table 3: Machine links

\begin{tabular}{|l|l|}
\hline $\begin{array}{l}\text { COEFFICIENT } \\
\text { VALUES }\end{array}$ & $\begin{array}{l}\text { MACHINE } \\
\text { LINKS }\end{array}$ \\
\hline 0.392 & $4 \& 6$ \\
\hline 0.620 & $7 \& 8$ \\
\hline 0.538 & 3 \& 7 \\
\hline 0.461 & $1 \& 5$ \\
\hline 0.384 & $2 \& 4$ \\
\hline 0.376 & 5 \& 9 \\
\hline 0.298 & $9 \& 10$ \\
\hline 0.196 & $6 \& 9$ \\
\hline 0.147 & $8 \& 9$ \\
\hline
\end{tabular}

Table 4: Selection of Routing by ICMD

\begin{tabular}{|c|c|c|c|c|c|c|c|c|c|c|c|c|}
\hline \multicolumn{2}{|c|}{ Machines } & \multirow[t]{2}{*}{3} & \multirow[t]{2}{*}{7} & \multirow[t]{2}{*}{8} & \multirow[t]{2}{*}{2} & \multirow[t]{2}{*}{4} & \multirow[t]{2}{*}{6} & \multirow[t]{2}{*}{1} & \multirow[t]{2}{*}{5} & \multirow[t]{2}{*}{9} & \multirow[t]{2}{*}{10} & \multirow{2}{*}{$\begin{array}{l}\text { IC } \\
\text { M } \\
\text { D }\end{array}$} \\
\hline Parts & $\begin{array}{l}\text { Rout } \\
\text { es }\end{array}$ & & & & & & & & & & & \\
\hline \multirow[t]{3}{*}{1} & 1 & & & & 2 & 3 & & 1 & & & & 1 \\
\hline & 2 & & & & 1 & 2 & 3 & & & & & 0 \\
\hline & 3 & 1 & & & & 2 & & & 3 & & & 2 \\
\hline \multirow[t]{2}{*}{2} & 1 & & 2 & 1 & & & & & 3 & & & 2 \\
\hline & 2 & & & & & & & 1 & 4 & 3 & 2 & 0 \\
\hline
\end{tabular}

Published By: 


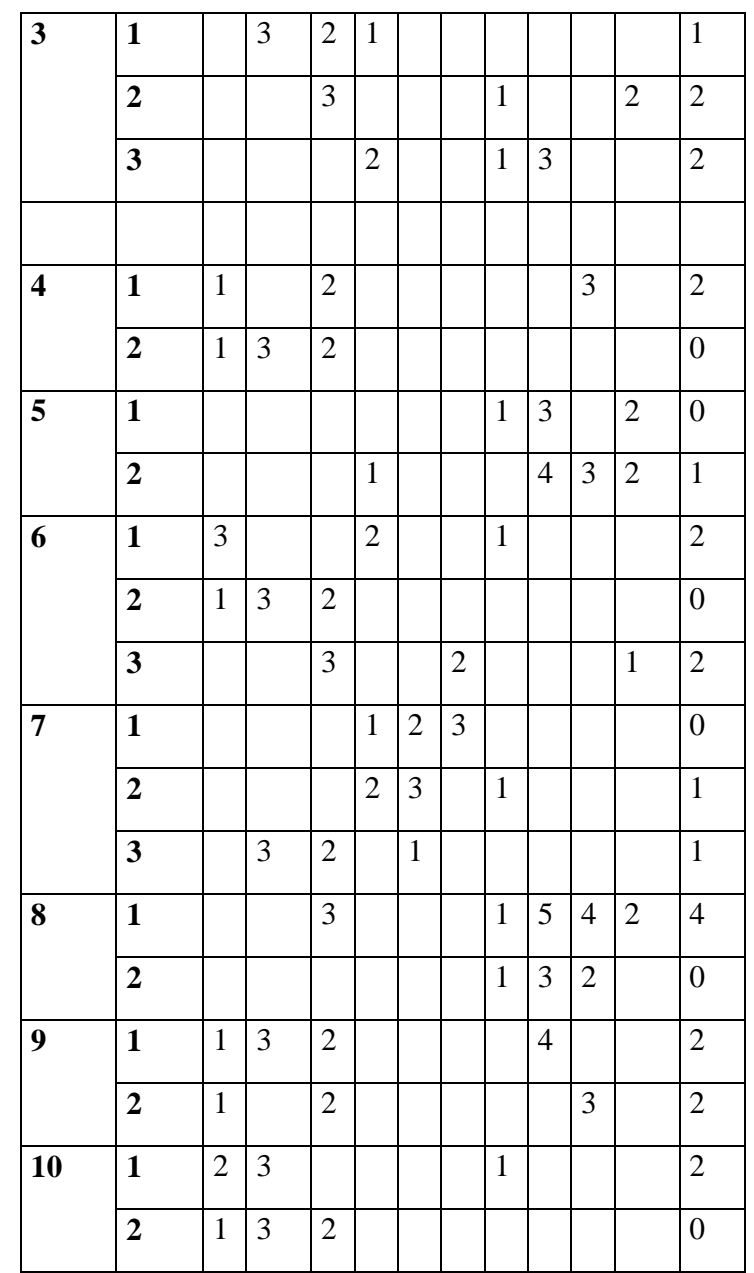

Table 5: Part coefficient matrix

\begin{tabular}{|c|c|c|c|c|c|c|c|c|c|c|}
\hline $\mathbf{P}$ & $\mathbf{1}$ & $\mathbf{2}$ & $\mathbf{3}$ & $\mathbf{4}$ & $\mathbf{5}$ & $\mathbf{6}$ & $\mathbf{7}$ & $\mathbf{8}$ & $\mathbf{9}$ & $\mathbf{1 0}$ \\
$\mathbf{P}$ & & & & & & & & & \\
\hline $\mathbf{1}$ & - & 0.15 & 0.28 & 0.17 & 0.17 & 0.17 & 0.47 & 0.17 & 0.15 & 0.17 \\
\hline $\mathbf{2}$ & & - & 0.15 & 0.15 & 0.46 & 0.14 & 0.14 & 0.46 & 0.25 & 0.15 \\
\hline $\mathbf{3}$ & & & - & 0.38 & 0.17 & 0.38 & 0.28 & 0.17 & 0.37 & 0.38 \\
\hline $\mathbf{4}$ & & & & - & 0.17 & 0.47 & 0.17 & 0.17 & 0.46 & 0.47 \\
\hline $\mathbf{5}$ & & & & & - & 0.17 & 0.17 & 0.38 & 0.26 & 0.17 \\
\hline $\mathbf{6}$ & & & & & & - & 0.17 & 0.17 & 0.46 & 0.47 \\
\hline $\mathbf{7}$ & & & & & & & - & 0.17 & 0.15 & 0.17 \\
\hline $\mathbf{8}$ & & & & & & & & - & 0.26 & 0.17 \\
\hline $\mathbf{9}$ & & & & & & & & & - & 0.46 \\
\hline $\mathbf{1 0}$ & & & & & & & & & & - \\
\hline
\end{tabular}

Table 6: Part Links

\begin{tabular}{|l|l|}
\hline $\begin{array}{l}\text { COEFFICIENT } \\
\text { VALUES }\end{array}$ & PART LINKS \\
\hline 0.468 & $1 \& 7$ \\
\hline 0.468 & $4 \& 10$ \\
\hline 0.468 & $6 \& 10$ \\
\hline 0.461 & $2 \& 8$ \\
\hline 0.461 & $9 \& 10$ \\
\hline 0.376 & $3 \& 10$ \\
\hline 0.376 & $5 \& 8$ \\
\hline 0.264 & $8 \& 9$ \\
\hline 0.166 & $7 \& 10$ \\
\hline
\end{tabular}

Step 6: Intracellular Machine Arrangement
After the formation of machine cells and part families, intracellular machine arrangement is made for each unit cell by means of the index matrix. In this step, the best machine sequence for each cell is determined so as to increase the forward flow as well as to reduce the backward flow which will in turn reduce the overall production time. The final machine part matrix is formed after the intracellular machine arrangement is made as shown in the Table 7.

The solution provided by chin chih et al (2013) is as given below:

\begin{tabular}{|l|l|l|l|l|l|l|l|l|l|l|}
\hline $\mathbf{P}$ & $\mathbf{1}$ & $\mathbf{2}$ & $\mathbf{3}$ & $\mathbf{4}$ & $\mathbf{5}$ & $\mathbf{6}$ & $\mathbf{7}$ & $\mathbf{8}$ & $\mathbf{9}$ & $\mathbf{1 0}$ \\
\hline 4 & 1 & 2 & & & & & & & & \\
\hline 2 & 2 & 1 & & & & & 1 & & & \\
\hline 6 & 3 & 3 & & & & & & & & \\
\hline 3 & & & 1 & 1 & 1 & 1 & & & & \\
\hline 8 & & & 2 & 2 & 2 & 2 & 2 & & & \\
\hline 7 & & & 3 & 3 & 3 & 3 & 3 & & & \\
\hline 1 & & & & & & & & 1 & 1 & 1 \\
\hline 10 & & & & & & & & 2 & & 2 \\
\hline 9 & & & & & & & & 3 & 2 & \\
\hline 5 & & & & & & 4 & & 4 & 3 & 3 \\
\hline
\end{tabular}

Table 7: Final solution by proposed approach

$>$ Cell 1: Machines 3, 8 \& 7 Parts 4, 6, 9 \& 10

Cell 2: Machines 2, 4 \& 6 Parts 1 \& 7

Cell 3: Machines 1,10,9 \& 5 Parts 2, 3, 5 \& 8

\section{MEASURING PARAMETERS}

\section{Forward Flow Ratio (FFR)}

It is the ratio of 'actual number of forward flow' to the 'maximum number of forward flow of the parts possible in the cell'

$$
F F R=\frac{\text { actual forward flow }\left(f_{n}\right)}{\text { maximun forward flow possible }\left(f_{\max }\right)}
$$

\section{Backward Flow Ratio (BFR)}

It is the ratio of actual number of backward flow to maximum number of possible backward flows of the parts in the cells.

$$
B F R=\frac{\text { actual backward flow }\left(b_{n}\right)}{\text { maximun backward flow possible }\left(b_{\max }\right)}
$$

\section{Intercell Movement Ratio (ICMR)}

It is the ratio of actual number of inters cell movement to maximum number of intercell movement possible.

$$
\begin{aligned}
& I C M R \frac{\text { inter cell movement }(I M)}{\text { max inter cell movement possible }\left(I M_{\max }\right)} \\
& I M_{\max }=\sum_{k=0}^{k} \mathrm{n}-1
\end{aligned}
$$

where, $\mathrm{n}=$ number of operations

$$
\mathrm{k}=\text { number of parts }
$$

\section{Skip Ratio (SR)}

It is the ratio of actual number of skips to the number of skips possible by the parts. 


\section{$S R=\frac{\text { actualskip }}{\text { maximunskippossible }}$}

If there are no voids at extreme, then

skip count $\max =\sum_{k=0}^{k} \mathrm{n}-2$

where, $\mathrm{n}=$ no. of operations within a cell.

If void is present between flow path

skip count $\max =\sum_{k=0}^{k} \mathrm{n}-2-1$

where, $\mathrm{l}=$ void -1 ,

$\mathrm{n}=$ no. of operations within a cell + voids.

\section{Evaluation of Proposed Approach}

a) Maximum number of flows possible $=20$

b) Number of forward flows $=19$

c) Number of backward flows $=1$

d) Maximum number of intercell movements possible = $\sum_{k=0}^{10} \mathrm{n}-1=2+2+2+2+2+3+2+3+2+2=22$

e) Actual number of intercell movement $=2$

i.e., in cell 2 , part $4-4^{\text {th }}$ operation takes place in cell 3

(Hence, IM =1) also, in cell 2,part $5-1^{\text {st }}$ operation takes place in cell 1 (Hence, IM = 1)

f) Maximum number of skips possible $=15$ i.e., in cell 3, there are 3 parts.

Part 1: $\mathrm{n}=4$, voids $=0$, so $\mathrm{l}=0$.

Part 2: $n=4$, voids $=1$, so $\mathrm{l}=0$.

Part 3: $\mathrm{n}=4$, voids $=1$, so $\mathrm{l}=0$.

Skip count $=\sum_{k=0}^{3} \mathrm{n}-2-1=3+3+3=9$

Similarly, considering all cells, maximum skip=15.

g) Actual number of skips possible $=3$

In cell 1 , part $2-2^{\text {nd }}$ operation $-1^{\text {st }}$ machine - 3rd operation $-3^{\text {rd }}$ machine

Now, skip count $=1$.

Similarly, considering all cells, actual number of skips $=3$.

FFR $=19 / 20=0.95$

$\mathrm{BFR}=1 / 20=0.05$

IMR $=2 / 22=0.09$

$\mathrm{SR}=3 / 15=0.20$

Table 8: Results and comparison

\begin{tabular}{|c|c|c|c|c|c|c|c|c|c|c|}
\hline \multirow[t]{2}{*}{$\begin{array}{l}\text { S. } \\
\text { No }\end{array}$} & \multirow[t]{2}{*}{$\begin{array}{c}\text { Probl } \\
\text { em } \\
\text { Size }\end{array}$} & \multirow[t]{2}{*}{ Source } & \multicolumn{4}{|c|}{$\begin{array}{l}\text { Results from previous } \\
\text { Literature }\end{array}$} & \multicolumn{4}{|c|}{$\begin{array}{c}\text { Results from } \\
\text { Proposed } \\
\text { Approach }\end{array}$} \\
\hline & & & $\begin{array}{c}\text { FF } \\
\mathbf{R}\end{array}$ & BFR & IMR & SR & FFR & BFR & $\begin{array}{c}\mathbf{I} \\
\mathbf{M} \\
\mathbf{R}\end{array}$ & $\begin{array}{l}\mathbf{S} \\
\mathbf{R}\end{array}$ \\
\hline 1 & $\begin{array}{l}20 x \\
20\end{array}$ & $\begin{array}{l}\text { Harhalakis } \\
\text { et al } 1990\end{array}$ & $\begin{array}{l}0.5 \\
2\end{array}$ & 0.38 & 0.31 & 0.56 & 0.64 & 0.23 & $\begin{array}{l}0 . \\
32\end{array}$ & $\begin{array}{l}0 . \\
28\end{array}$ \\
\hline 2 & $8 \times 6$ & $\begin{array}{l}\text { Chin-chih } \\
\text { et al } 2013\end{array}$ & $\begin{array}{l}0.8 \\
8 \\
\end{array}$ & 0.11 & 0.33 & 0.18 & 0.88 & 0.11 & $\begin{array}{l}0 . \\
33 \\
\end{array}$ & $\begin{array}{l}0 . \\
18 \\
\end{array}$ \\
\hline 3 & $8 \times 20$ & $\begin{array}{l}\text { Harhalakis } \\
\text { et al } 1990\end{array}$ & $\begin{array}{l}0.3 \\
2\end{array}$ & 0.31 & 0.39 & 0.42 & 0.53 & 0.25 & $\begin{array}{l}0 . \\
39 \\
\end{array}$ & $\begin{array}{l}0 . \\
42\end{array}$ \\
\hline 4 & $6 \times 8$ & $\begin{array}{l}\text { Raja \& } \\
\text { Anbumalar } \\
2016 \\
\end{array}$ & $\begin{array}{l}0.6 \\
6\end{array}$ & 0.33 & 0.07 & 0.83 & 0.83 & 0.16 & $\begin{array}{l}0 . \\
07\end{array}$ & $\begin{array}{l}0 . \\
66\end{array}$ \\
\hline 5 & $\begin{array}{l}10 x \\
10\end{array}$ & $\begin{array}{l}\text { Chin-chih } \\
\text { et al } 2013\end{array}$ & $\begin{array}{l}0.9 \\
5\end{array}$ & 0.05 & 0.09 & 0.2 & 0.95 & 0.05 & $\begin{array}{l}0 . \\
09\end{array}$ & $\begin{array}{l}0 . \\
2\end{array}$ \\
\hline
\end{tabular}

VII. RESULT AND DISCUSSION

In this study, importance has been given to the sequence of operations. For normal cases and cases involving alternate routes, four parameters have been introduced for evaluation and these parameters are used to compare the results of proposed method with the results from different literatures to show that the results are better. The desirable parameters are FFR is higher in problems $20 \times 20,8 \times 20,6$ x 6 and equal in problems $8 \times 6,10 \times 10$. With this, we can ascertain that the proposed approach is better than the previous approaches.

The results are shown in graph 1 . Next, in case of undesirable parameters, BFR, it is proved that backward flow is reduced in the proposed approach as compared to the literature approaches.

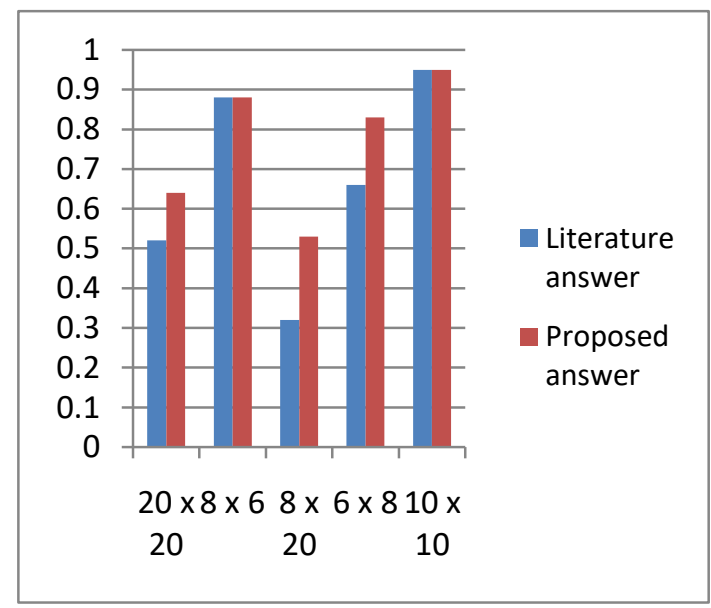

Fig 1. FFR comparison graph

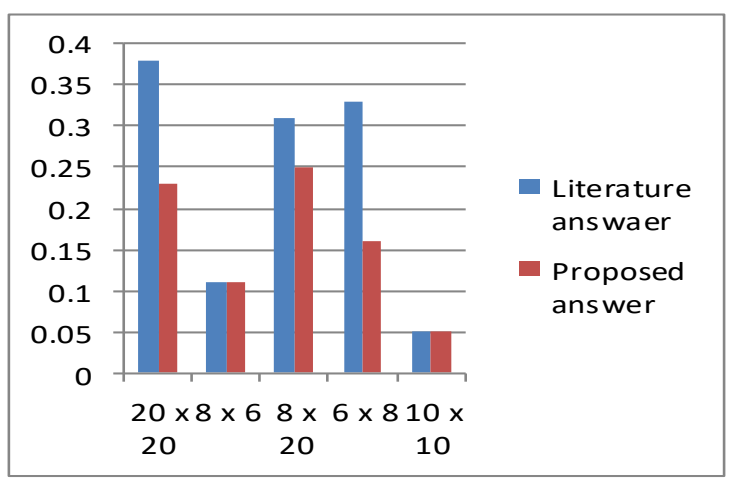

Fig 2. BFR comparison graph

Backward flow is reduced in problems $20 \times 20,8 \times 20,6 \times 8$ and is equal in problems $8 \times 6,10 \times 10$ which further validates, the credibility of the proposed approach. The results are shown in graph 2 . Result and comparison values are in Table 8.In case of IMR, it is same in all other problems but is slightly increased in problem $20 \times 20$, which is acceptable as all other parameters give better results. Considering SR, the results obtained is satisfactory as there is decrease in the overall count of skip of parts between machines. The number of skips is reduced in problems $20 \mathrm{x}$ 20, 6 × 8 and is equal in problems $20 \times 20,8 \times 6$ and $10 \times 10$. 


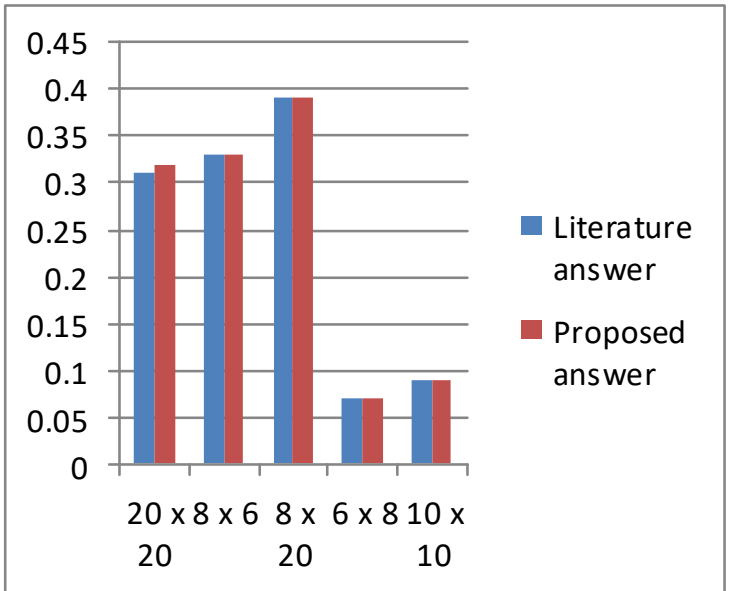

Fig 3. IMR comparison graph

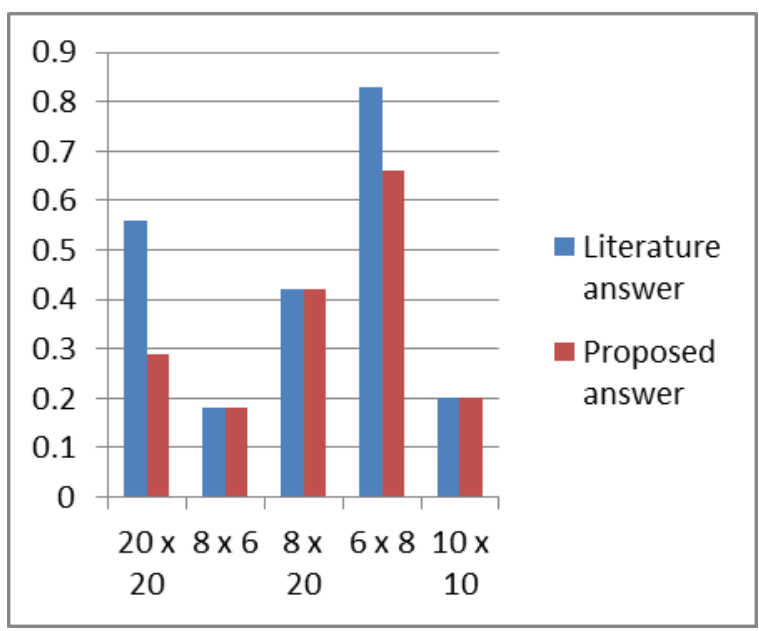

Fig 4. SR comparison graph

\section{CONCLUSION}

A lot of study has been made on cellular manufacturing and many people have contributed for the improvement of the concept cellular manufacturing, but improvement of sequence of operation which has not seen major improvement has been taken as the primary objective and a new simple method has been successfully formulated. The newly formulated method has been evaluated with the help of four measuring parameters. The results obtained from these parameters through comparison with standard literature problems are more than satisfactory as it indicates that with the application of this method (in normal cases and also cases involving multiple routings) in industry, production rate is increased, movement cost and time is reduced, etc., So this method can be applied in real life with consideration of additional production factors like layout size, quantity of production, etc.,

\section{REFERENCES}

1. Abtin nourmohammadzadeh ,Hamed Rafiei, Hossein Dashti, Masoud Rabbani (2013) 'Cell formation problem with alternative process plans alternative routes considering defect rate', International Journal of Scientific \& Engineering Reasearch, Vol. 4, No. 5.

2. Amit Rai Dixit and Mishra, P.K. (2007) 'Heuristic based approach of Cell Formation considering Operation Sequence', Proceedings of World Congress on Engineering, Vol. II, WCE 2007, London, U.K.

3. Busaba Phruksaphanrat and Nittaya Ngampak (2011) 'Cellular Manufacturing Layout Design and Selection: A case Study of
Electronic Manufacturing Service Plant', proceedings of international MultiConference of Engineers and Computer Scientists, Vol. II , Hong Kong.

4. Chalapathi, P.V. (2012) 'Complete Design of Cellular Manufacturing Systems', International Journal of Advanced Engineering Technology 0976-3945.

5. Chin-Chih Chang, Feng-Chia Li, Tai- hsi Wu, 'An sufficient tabu search approach to determine cell formation, cell layout, and intracellular machine layout in the cellular manufacturing system'.

6. Chin-Chih Chang, Tai-Hsi Wu (2011) 'A water flow-like algorithm or cellular manufacturing design and layout', International Conference on Advanced Information Technologies (AIT)

7. Chin-chih chang, Tai-Hsi Wu and Chien-Wei Wu (2013) 'An Efficient Approach to Determine Cell Formation, Cell Layout and Intra cellular Machine Sequence in Cellular Manufacturing Systems', Computers \& Industrial Engineering Vol. 66 pp.438-450.

8. Dipak Laha and Manash Hazarika (2016) 'A Heuristic Approach for Machine Cell Formation Problems with Alternative Routings',Twelfth International Multi-Conference on Information Processing (IMCIP).

9. Farouq Alhourani (2013) 'Clustering algorithm for solving group technology problem with multiple process routings', Computers and Industrial Engineering Vol. 66 pp.781-790.

10. Harhalakis G, Nagi R, Proth JM. (1990), 'An efficient heuristic in manufacturing cell formation for group technology applications', International Journal of Production Research Vol.28, pp.185-198

11. Jamal Arkat, Mohammad Saeed Ameli (2006) 'Cell formation with alternative process routings and machine reliability consideration',Int J Adv ManufTechnol Vol. 35: pp.761-768.

12. Murugan, M. and Selladuari, V. (2011) 'Formation of Machine Cells/Part Families in Cellular Manufacturing Systems Using an ART-Modified Single Linkage Clustering Approach - A Comparative Study', Jordan Journal of Mechanical and Industrial Engineering, Vol 5, No. 3

13. Raja, S., \& Anbumalar, V. (2016a), 'An effective methodology for cell formation and intra - cell machine layout design in cellular manufacturing system using parts visit data and operation sequence data',. The Brazilian Society of Mechanical Sciences and Engineering; Vol. 38, pp. 869-882.

14. Raja, S., \& Anbumalar, V. (2016b), 'A new method for integrating feasibility assessment and cell formation problem considering operation sequence', International journal of Advanced 608 Engineering Technology, Vol. 7, No.1,pp. 544, 551.

\section{AUTHORS PROFILE}

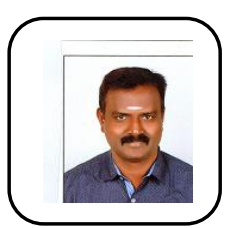

Dr. S. Raja received his BE. Degree from Madurai Kamarajar university, Madurai, India, M.E., Industrial Engineering degree from Madurai Kamarajar University, Madurai, India and Ph.D degree from Anna University, Chennai, India. He is currently working as a Professor in the Department of Mechanical Engineering at PSNA College of Engineering and Technology, Dindigul, India. He has published more than 20 research articles in various international journals. He is acting as a reviewer in various international journals. He is a life time member of ISTE.

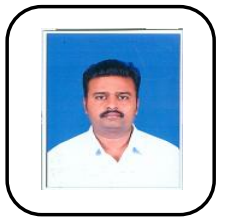

Dr. K. Muralidharan received his BE. Degree from Madurai Kamarajar university, Madurai, India, M.Tech., Energy Engineering degree from Regional Engineering College, Trichyi, India and Ph.D degree from Anna University, Chennai, India. He is currently working as a Professor in the Department of Mechanical Engineering at PSNA College of Engineering and Technology, Dindigul, India. He has published more than 20 research articles in various international journals. He is acting as a reviewer in various international journals. He is a life time member of ISTE. 


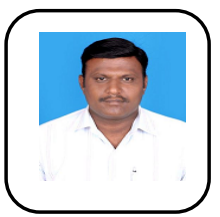

Mr.S.Karthik is Assistant Professor of Department of Mechanical Engineering at PSNA College of Engineering and Technology, Dindigul with over 9 years of teaching and 5 years of research experience. He has published more than 5 international journals and made 10 international conference presentations. His areas of specializations are alternative fuel, aerofoil and CFD.

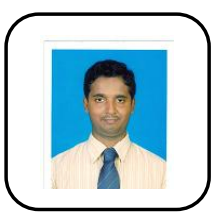

Mr.K.Rajasuthan has been awarded B.E degree from Raja college of engineering and technology affiliated to Madurai kamaraj university and M.E degree from Mepco schlenk engineering college affiliated to Anna university, Chennai. He is currently working as Assistant professor in the department of mechanical engineering at PSNA college of engineering and technology, Dindigul.He has a sum of fifteen years of experience in teaching field and has nearly fifteen research publications. 